\title{
Environmental occurrence and distribution of organic UV stabilizers and UV filters in the sediment of Chinese Bohai and Yellow Seas ${ }^{\text {th }}$
}

\author{
Christina Apel a, c, *, Jianhui Tang ${ }^{b, * *}$, Ralf Ebinghaus ${ }^{a}$ \\ ${ }^{a}$ Helmholtz-Zentrum Geesthacht, Institute of Coastal Research, 21502 Geesthacht, Germany \\ ${ }^{\mathrm{b}}$ Yantai Institute of Coastal Zone Research, Chinese Academy of Sciences, Yantai 264003, China \\ ${ }^{\text {c }}$ University of Hamburg, Institute of Inorganic and Applied Chemistry, 20146 Hamburg, Germany
}

\section{A R T I C L E I N F O}

\section{Article history:}

Received 8 August 2017

Received in revised form 14 December 2017

Accepted 14 December 2017

Available online 21 December 2017

\section{Keywords:}

UV stabilizers

UV filters

Benzotriazole derivatives

Marine sediments

Bohai sea

Yellow sea

\begin{abstract}
A B S T R A C T
Organic UV stabilizers and UV filters are applied to industrial materials and cosmetics worldwide. In plastics they prevent photo-induced degradation, while in cosmetics they protect human skin against harmful effects of UV radiation. This study reports on the occurrence and distribution of organic UV stabilizers and UV filters in the surface sediment of the Chinese Bohai and Yellow Seas for the first time. In total, 16 out of 21 analyzed substances were positively detected. Concentrations ranged from sub-ng/g $\mathrm{dw}$ to low $\mathrm{ng} / \mathrm{g} \mathrm{dw}$. The highest concentration of $25 \mathrm{ng} / \mathrm{g} \mathrm{dw}$ was found for octocrylene (OC) in the Laizhou Bay. In the study area, characteristic composition profiles could be identified. In Korea Bay, the dominating substances were OC and ethylhexyl salicylate (EHS). All other analytes were below their method quantification limit (MQL). Around the Shandong Peninsula, highest concentrations of benzotriazole derivatives were observed in this study with octrizole (UV-329) as the predominant compound, reaching concentrations of $6.09 \mathrm{ng} / \mathrm{g} \mathrm{dw}$. The distribution pattern of UV-329 and bumetrizole (UV-326) were related (Pearson correlation coefficient $r>0.98, \mathrm{p}$ « 0.01 around the Shandong Peninsula), indicating an identical input pathway and similar environmental behavior.
\end{abstract}

(c) 2017 Elsevier Ltd. All rights reserved.

\section{Introduction}

UV absorbing compounds are widely used in personal care products, textiles, plastics, paints, adhesives, rubber, and other industrial products (Avagyan et al., 2015; Kim et al., 2011b; Ramos et al., 2015). Depending on their purpose, they can be divided into two categories as described by Langford et al. (2015): i) UV stabilizers are added to plastic products (and other materials) to prevent UV-induced degradation and discoloring of the product and ii) UV filters are used in personal care products (PCPs) such as sunscreens and cosmetics to protect human skin and hair against UV radiation. Some compounds are used for both purposes, whereby a strict differentiation is not possible. Therefore, the term "UV stabilizer" is used for all compounds in the following.

UV stabilizers used in PCPs are regulated worldwide. In Europe, Annex VI of the Cosmetic Regulation No. 1223/2009 (European
Commission, 2017) provides a positive list of substances allowed in cosmetic products. In China, the same substances are permitted as in Europe.

The input pathways of UV stabilizers to the marine environment are mainly indirect, through wastewater treatment plant discharges, or direct, through recreational activities such as bathing and swimming (Poiger et al., 2004; Ramos et al., 2016). Microplastic and plastic debris are also discussed as potential sources of plastic additives (Cole et al., 2011; Rani et al., 2015, 2017).

Some UV stabilizers are currently listed as High Production Volume Chemicals (HPVC) by the OECD (2017). Due to the widespread usage and high production volumes, UV stabilizers are present in various environmental matrices. UV stabilizers have been reported worldwide in water (Balmer et al., 2005; Cunha et al., 2015b; Kameda et al., 2011; Liu et al., 2014; Tsui et al., 2014), suspended particulate matter (Wick et al., 2016), house dust (Kim et al.,

\footnotetext{
This paper has been recommended for acceptance by Eddy Y. Zeng.

* Corresponding author. Helmholtz-Zentrum Geesthacht, Institute of Coastal Research, 21502 Geesthacht, Germany.

** Corresponding author.

E-mail addresses: christina.apel@hzg.de (C. Apel), jhtang@yic.ac.cn (J. Tang).
} 
2012), sediment (Kameda et al., 2011; Langford et al., 2015; Nakata et al., 2009; Wick et al., 2016), and biota (Cunha et al., 2015a; GagoFerrero et al., 2012; Langford et al., 2015; Nakata et al., 2012; Peng et al., 2015; Sang and Leung, 2016; Wick et al., 2016). For example, Huang et al. (2016) had identified three UV stabilizers in sediment samples from China's Pearl River estuary with the highest concentrations of ethylhexyl methoxycinnamate (EHMC) and octocrylene (OC) (around $0.5 \mu \mathrm{g} / \mathrm{g} \mathrm{dw}$ ) in fishing harbors. Most UV stabilizers are hydrophobic compounds with high octanol-water partition coefficients $\left(\log \mathrm{K}_{\mathrm{ow}}>3\right)$ and show significant accumulation potentials in suspended matter, sediments, and biota. Some substances show persistent, bioaccumulative, and toxic (PBT) properties. For this reason, four benzotriazole UV stabilizers are currently listed as Substances of Very High Concern (SVHC) under the EU legislation REACH (ECHA, 2017a). Namely, these substances are 2-(Benzotriazol-2-yl)-4,6-di-tert-butylphenol (UV-320), 2,4-ditert-Butyl-6-(5-chlorobenzotriazol-2-yl) phenol (UV-327), 2-(Benzotriazol-2-yl)-4,6-bis-(1,1-dimethyl-propyl) phenol (UV-328), and 2-(Benzotriazol-2-yl)-6-butan-2-yl-4-tert-butylphenol (UV-350). In addition, EHMC is included in the Watch List to be monitored under the Water Framework Directive (European Commission, 2015).

The widespread contamination and the resulting potential exposure of UV stabilizers have raised increasing concern about their impact on ecosystems and human health. There is increasing evidence to the adverse effects of UV stabilizers. Many UV stabilizers, such as benzophenones, camphor and cinnamate derivatives, have been identified as potential endocrine disruptors (Balazs et al., 2016; Wang et al., 2016). Several compounds are a major cause of coral bleaching (Danovaro et al., 2008) and show hormonal activity and toxicity in in vivo rat model systems (Rainieri et al., 2017). So far, for benzotriazole UV stabilizers no estrogenic and androgenic activities have been observed in zebrafish eleuthero-embryos (Fent et al., 2014), but exposure to UV-P and UV-326 may lead to metabolic imbalance and developmental toxicity (Fent et al., 2014). At environmental concentration levels, benzotriazole UV stabilizers were shown to have no acute toxicity in Daphnia (Kim et al., 2011a). Toxicity studies showed that direct contact with UV-P might cause acute effects such as dermatitis and skin irritation (Yamano et al., 2001). Benzotriazole UV stabilizers interacted with the human serum albumin (Zhuang et al., 2016) and showed activity toward the human aryl hydrocarbon receptor (AhR), which could adversely affect the immune response (Nagayoshi et al., 2015).

While the widespread occurrence of UV stabilizers is known, only few studies focused on the marine environment. The main aim of this study was to assess the significance of UV stabilizers as emerging contaminants in the sediment of the Chinese Bohai and Yellow Seas.

The Bohai Sea is surrounded by the Bohai Economical Rim (BER), which is the largest economic engine in North China. It includes megacities such as Beijing and Tianjin and comprises parts of the Hebei, Shandong, and Liaoning provinces. Many chemical pollutants, such as per- and polyfluorinated substances (Heydebreck et al., 2015; Wang et al., 2014) and organophosphate esters (Wang et al., 2015) are transported by rivers into the Bohai Sea and pose a great risk for aquatic wildlife (Zhang et al., 2017). Large volumes of domestic and industrial discharges are entering the Bohai Sea as well as the Yellow Sea, significantly deteriorating the water quality (Wang et al., 2015; Zhong et al., 2018).

In this work, surface sediment samples were collected and analyzed for 20 UV stabilizers and one hindered amine light stabilizer (HALS) to i) evaluate the current pollution status, ii) characterize regions, iii) identify potential contamination sources, and iv) give a preliminary risk evaluation of UV stabilizers in the Bohai and Yellow Seas.

\section{Material and methods}

\subsection{Chemicals}

Enzacamene (4-MBC), Iscotrizinol (DBT), Ethylhexyl triazone (EHT), Ethylhexyl methoxycinnamate (EHMC), Octocrylene (OC), Bumetrizole (UV-326), 2,4-di-tert-Butyl-6-(5-chlorobenzotriazol2-yl) phenol (UV-327), 2-(Benzotriazol-2-yl)-4,6-bis-(1,1dimethyl-propyl) phenol (UV-328), Ethylhexyl methoxycinnamate- $\mathrm{d}_{15}$ (EHMC- $\left.\mathrm{d}_{15}\right)$, Homosalate- $\mathrm{d}_{4}\left(\right.$ HMS- $\left.\mathrm{d}_{4}\right)$, Octocrylene- $\mathrm{d}_{15}\left(\mathrm{OC}-\mathrm{d}_{15}\right)$, and Benzophenone- $\mathrm{d}_{10}\left(B P-\mathrm{d}_{10}\right)$ were purchased from Sigma-Aldrich (Germany). Oxybenzone (BP-3), Octabenzone (BP-12), Ethylhexyl salicylate (EHS), Bis[4-(2-phenyl-2-propyl) phenyl] amine (HALS-445), Homosalate (HMS), Amiloxate (IAMC), Padimate O (OD-PABA), Drometrizole (UV-P), 2-(5-tert-butyl-2hydroxyphenyl) benzotriazole (UV-PS), Octrizole (UV-329), and 2(Benzotriazol-2-yl)-4,6-bis-(2-phenylpropan-2-yl) phenol (UV234) were obtained from TCI Deutschland GmbH (Germany). 2(Benzotriazol-2-yl)-6-butan-2-yl-4-tert-butylphenol (UV-350), 2(Benzotriazol-2-yl)-4,6-di-tert-butylphenol (UV-320), and 2-(Benzotriazol-2-yl)-4-methyl-6-(2-propenyl) phenol (Allyl-bzt) were supplied by amchro $\mathrm{GmbH}$ (Germany). Enzacamene- $\mathrm{d}_{4}\left(4-\mathrm{MBC}-\mathrm{d}_{4}\right)$ and Oxybenzone- ${ }^{13} \mathrm{C}_{6}\left(\mathrm{BP}-3-{ }^{13} \mathrm{C}_{6}\right)$ were distributed by EQ Laboratories $\mathrm{GmbH}$ (Germany) and LGC Standards GmbH (Germany), respectively. 2-(2-Hydroxy-5-methylphenyl)-benzotriazole- $\mathrm{d}_{4}$ (UV-P-d $\left.\mathrm{d}_{4}\right), \quad$ 2-(Benzotriazol-2-yl)-4,6-bis-(1,1-dimethyl-propyl) phenol- $\mathrm{d}_{4}\left(\mathrm{UV}-328-\mathrm{d}_{4}\right)$, and Perfluoro-1-[ $\left.{ }^{13} \mathrm{C}_{8}\right]$-octanesulfonamide (FOSA $-{ }^{13} \mathrm{C}_{8}$ ) were supplied by CAMPRO Scientific GmbH (Germany). Further information such as structures, CAS-No., chemical names, and purities can be found in Tables S1 and S2 of the Supplementary Material.

Dichloromethane (Picograde) was purchased from LGC Standards (Germany). Both methanol (LiChrosolv, hypergrade for LCMS) and toluene (LiChrosolv, for liquid chromatography) were purchased from Merck (Germany). Deionized water was supplied from a Milli-Q Integral 5 system (Germany).

\subsection{Study area and sample collection}

The Bohai and Yellow Seas are semi-enclosed marginal seas in the northwest Pacific Ocean. The Yellow Sea is surrounded by the west coast of the Korean Peninsula and the east coast of China. It has an area of approximately $380,000 \mathrm{~km}^{2}$ (Song, 2010) and an average depth of $44 \mathrm{~m}$ (Song, 2010). Its northern extension is referred to as Korea Bay and in the northwest, the Yellow Sea is connected to the Bohai Sea through the Bohai Strait. The Bohai Sea has an area of approximately $77,000 \mathrm{~km}^{2}$ (Song, 2010) and features three bays, one of them being Laizhou Bay in the south.

Surface sediment samples from the Bohai and Yellow Seas were collected in June and July 2016 on the Chinese research vessel Dongfanghong 2 sampling campaign. Surface sediment samples from Laizhou Bay were collected in July 2016 on the Chuangxin 1 sampling cruise. On both campaigns the samples were taken using a stainless-steel box corer and the top $10 \mathrm{~cm}$ of sediment was collected. Samples were put afterward into pre-cleaned (cleaned with acetone and baked out at $250^{\circ} \mathrm{C}$ ) aluminum bowls and stored at $-20^{\circ} \mathrm{C}$ until sample preparation. Detailed sampling information can be found in Table S7 of the Supplementary Material.

\subsection{Sample preparation}

The wet sediment samples were freeze-dried (Christ Alpha 1-4 LDplus, Germany) and homogenized using a laboratory mortar. Large pieces (such as seashells and stones) were removed. Afterward, extraction and clean-up were performed simultaneously 
using an accelerated solvent extraction (DIONEX ASE-350) method. For this, $22 \mathrm{~mL}$ stainless steel ASE cells were filled in layers with $3 \mathrm{~g}$ of $10 \%$ deactivated silica and $5-8 \mathrm{~g}$ of dried sediment. The sediment samples were spiked with the isotopically labeled standards 4MBC- $\mathrm{d}_{4}, B P-3-{ }^{13} \mathrm{C}_{6}$, EHMC- $\mathrm{d}_{15}, \mathrm{HMS}-\mathrm{d}_{4}, \mathrm{OC}-\mathrm{d}_{15}$, and the nonlabeled surrogate standard Allyl-bzt. For most of the Bohai Sea samples and all Yellow Sea samples Allyl-bzt could be replaced by UV-P- $\mathrm{d}_{4}$ and UV-328- $\mathrm{d}_{4}$, which became commercially available. Depending on the substance response, internal standards were added at absolute quantities of $2-10 \mathrm{ng}$. The cells were extracted using dichloromethane for three $15-\mathrm{min}$ cycles at $100^{\circ} \mathrm{C}$. The ASE extract $(\sim 40 \mathrm{~mL})$ was solvent-changed to methanol in a rotary evaporator and reduced in volume to $150 \mu \mathrm{L}$ under a heated nitrogen stream. The reduced extract was $0.2 \mu \mathrm{m}$-filtered into a LC vial using a Spartan syringe filter $(\varnothing=13 \mathrm{~mm}$, Whatman, Germany). Finally, $65 \mu \mathrm{L}$ water was added (to obtain the needed solvent composition for the following LC-MS/MS analysis) and the extract was spiked with $2 \mathrm{ng}$ (absolute) of FOSA- ${ }^{13} \mathrm{C}_{8}$ and $\mathrm{BP}-\mathrm{d}_{10}$ as injection standards, resulting in a sample volume of $225 \mu \mathrm{L}$. For every sample, double measurements were conducted.

\subsection{LC-MS/MS analysis}

The instrumental analysis was performed on a UHPLC-MS/MS system (1290 Infinity coupled to 6490 triple quadrupole LC/MS; both from Agilent, Germany) equipped with an atmospheric pressure photoionization (APPI) source and both a C18 column (Eclipse Plus RRHD $1.8 \mu \mathrm{m}, 2.1 \times 150 \mathrm{~mm}$, Agilent, Germany) and a C8 column (Eclipse Plus RRHD $1.8 \mu \mathrm{m}, 2.1 \times 150 \mathrm{~mm}$, Agilent, Germany). The mobile phase consisted of A) water and B) methanol. Separation was achieved at a constant flow rate of $0.2 \mathrm{~mL} / \mathrm{min}$. The solvent gradient started with an isocratic segment of 70\% B (4 min), which was increased to $90 \%$ B over 3 min and held constant for another $5 \mathrm{~min}$. Over $1 \mathrm{~min}$, B was further increased to $100 \%$ and held constant for $13 \mathrm{~min}$. For enhanced ionization, 5\% toluene was added as a dopant post-column. Every sample was measured in positive and in negative ionization mode. Further information on the instrumental method is presented in the Supplementary Material.

\subsection{Total organic carbon (TOC) analysis}

TOC analysis was carried out with aliquots of the freeze-dried samples using a LECO RC612 multiphase (Germany). The $\mathrm{TOC}_{400^{-}}$ values were determined running a temperature program from $150{ }^{\circ} \mathrm{C}$ to $400^{\circ} \mathrm{C}$ at $70^{\circ} \mathrm{C} / \mathrm{min}$ in an oxygen flow. The final temperature was held for $2 \mathrm{~min}$. For every sample, a double measurement was conducted.

\subsection{Statistics and risk evaluation}

All statistical analyses were done in OriginPro 9.1 (OriginLab Corporation). Firstly, Shapiro-Wilk and Kolmogorov-Smirnov normality tests were performed. Whenever the results indicated that the UV stabilizer concentrations showed no normal distribution $(\mathrm{p}<.05)$, logarithmically transformed concentrations values were used for subsequent statistical analyses. To test for significant differences in concentration levels in the Laizhou Bay, other parts of the Bohai Sea, and the Yellow Sea, a test for homogeneity of variances (Levene's test) was conducted, followed by a one-way ANOVA test coupled with a Turkey post-hoc test (all at a significance level of 0.05 ). A Pearson correlation analysis was performed to evaluate correlations between total UV stabilizer concentrations and TOC contents as well as among concentrations of single UV stabilizers. For analyses, concentration values $<$ MDL were treated as zero and for concentration values $<\mathrm{MQL}$, the obtained concentration value was used.

The potential risk was evaluated according to Pintado-Herrera et al. (2017a). Hazard quotients (HQ) were calculated by dividing measured environmental concentrations (MEC) obtained from this study by predicted no effect concentrations (PNEC) obtained from the literature. In case no PNEC values were available, they were calculated from toxicity data by applying an assessment factor of 1000 for acute toxicity data and 100 for chronic toxicity data. For interpretation, HQ values $>1$ indicate to an ecological risk.

\subsection{Quality assurance and quality control}

Because of the widespread presence of UV stabilizers in a variety of laboratory equipment, the use of rubber and plastic materials was avoided to minimize blank contamination during the transport, storage and treatment of the samples. Prior to use, all glassware was cleaned by a laboratory dishwasher, baked at $250^{\circ} \mathrm{C}$, and rinsed with methanol.

For blank determination, sea sand (baked at $400^{\circ} \mathrm{C}$ ) was placed into the freeze-drying system together with the wet sediment samples and was treated as a sample throughout the entire sample preparation and measuring steps. Normally, each extraction batch (max. 24 ASE cells) consisted of three procedural blanks together with 20 samples ( 10 sediment samples in double measurement). The mean concentrations of UV stabilizers in the blanks ranged from $0.6 \pm 0.9 \mathrm{pg} / \mathrm{g}$ (HALS-445) to $19.6 \pm 6.7 \mathrm{pg} / \mathrm{g}$ (EHS). The OC contamination is higher $(248 \pm 28 \mathrm{pg} / \mathrm{g})$ and is mainly caused by the freeze drying procedure.

Quantification was performed using the internal standard calibration method. Solvent based calibration curves where used to obtain the relative response ratio of the target analyte to the amount of an appropriate mass-labeled standard using a $1 / x$ weighting factor. Substances without isotopically labeled standards available were corrected with the most fitting (in recovery and retention time) surrogate standard. For example, EHS was corrected by HMS- $\mathrm{d}_{4}$, as recovery tests with matrix resulted in high accordance of, for example, $105 \pm 7 \%$ (Supplementary Material, Table S5). The reported concentrations for BP-12 must be considered as semiquantitative, as the resulting concentrations are most likely overestimated due to different properties of BP-12 and the assigned internal standard (BP-3- ${ }^{13} \mathrm{C}_{6}$ ). However, as BP-12 was only found in low concentrations, the semiquantitative results do not have any consequences for discussion. Before and after every sample batch, a 10 -point calibration curve $(0.0-90 \mathrm{pg} / \mu \mathrm{L})$ was measured and extended whenever needed $(130,220,440 \mathrm{pg} / \mu \mathrm{L})$. All calibration curves were linear with correlation coefficients $>0.99$ for all analytes, except for DBT and EHT, which showed a lower linearity (normally $>0.91$ ). Method detection limits (MDLs) were derived from either the mean blank values plus three times the standard deviation or the signal-to-noise ratio of three $(\mathrm{S} / \mathrm{N}=3)$, whichever approach yielded the highest value. Accordingly, method quantification limits (MQLs) were derived from either the mean blank values plus ten times the standard deviation or the signal-to-noise ratio of ten $(\mathrm{S} / \mathrm{N}=10)$. MDLs and MQLs were calculated for every sample batch separately. Based on a sample volume of $8 \mathrm{~g}$, blank corrected MDLs ranged from 1 (OD-PABA) to $120 \mathrm{pg} / \mathrm{g}$ dw (4-MBC). More information on the method validation is presented in the Supplementary Material.

The mean absolute recoveries of the mass-labeled standards for all Bohai and Yellow Seas samples were $74 \pm 27 \%\left(4-\mathrm{MBC}_{4} \mathrm{~d}_{4}\right)$, $56 \pm 28 \%\left(\mathrm{BP}-3-{ }^{13} \mathrm{C}_{6}\right), 70 \pm 31 \%\left(\right.$ EHMC $\left.-\mathrm{d}_{15}\right), 58 \pm 29 \%\left(\mathrm{HMS}-\mathrm{d}_{4}\right)$, $72 \pm 31 \%\left(\right.$ OC- $\left._{15}\right), 81 \pm 22 \%\left(\mathrm{UV}-\mathrm{P}-\mathrm{d}_{4}\right), 87 \pm 61 \%\left(\mathrm{UV}-328-\mathrm{d}_{4}\right)$, and $71 \pm 39 \%$ (Allyl-bzt).

All presented concentrations are corrected for recovery and blank. 


\section{Results and discussion}

\subsection{Environmental concentrations of UV stabilizers in the Bohai and Yellow Seas}

Organic UV stabilizers could be detected in all surface sediment samples of the Bohai and Yellow Seas. Concentrations are shown in Fig. 1 and Table 1. In 16\% of the analyzed samples, all UV stabilizer concentrations were $<$ MQL. The concentrations of total UV stabilizers ( $\sum$ UV stabilizers) ranged from 0.06 to $25.7 \mathrm{ng} / \mathrm{g} \mathrm{dw}$ with average values of $3.9 \mathrm{ng} / \mathrm{g} \mathrm{dw}$ for Laizhou Bay, $0.6 \mathrm{ng} / \mathrm{g} \mathrm{dw}$ for the other parts of the Bohai Sea, and $2.1 \mathrm{ng} / \mathrm{g}$ dw for the Yellow Sea. No statistically different contamination levels were observed for these regions. The levels of the UV stabilizers UV-PS, UV-350, BP-3, IAMC, and 4-MBC were below their MDLs in all analyzed samples.

The predominant contaminants were OC and UV-329, accounting for $52 \%$ and $15 \%$ of total UV stabilizer contamination in the sediment. The highest detection frequency was found for UV-234 (69\%) followed by UV-326, UV-329, UV-328, and HALS-445 (all > 60\%).
A comparison with the concentrations among different regions may be better for understanding the pollution situation in China. Concentrations of UV stabilizers in coastal and marine sediments worldwide were summarized in Table 2 .

The UV stabilizer found in highest concentration in this study is OC. It was identified in $46 \%$ of samples with highest concentrations up to $25 \mathrm{ng} / \mathrm{g}$ dw at the central and outer Laizhou Bay (Fig. 1). In the other parts of the Bohai Sea, OC occurred in remarkably lower concentrations (up to $0.3 \mathrm{ng} / \mathrm{g} \mathrm{dw}$ ). These OC concentrations are similar to lower compared to reported coastal concentrations in other studies (Table 2). In the Bohai Sea, all other UV stabilizers occurred in lower concentrations than OC. EHS reached concentrations up to $1.2 \mathrm{ng} / \mathrm{g} \mathrm{dw}$, UV-326 up to $0.8 \mathrm{ng} / \mathrm{g} \mathrm{dw}$, and UV-327 up to $0.5 \mathrm{ng} / \mathrm{g} \mathrm{dw}$ in Laizhou Bay; other substance concentrations were $\leq 0.2 \mathrm{ng} / \mathrm{g} \mathrm{dw}$.

In the North Yellow Sea, both OC and EHS could be quantified in all Korea Bay samples in concentrations of $1.39 \pm 0.71 \mathrm{ng} / \mathrm{g} \mathrm{dw}$ and $0.76 \pm 0.36 \mathrm{ng} / \mathrm{g} \mathrm{dw}$, respectively. All other substance concentrations were $<$ MQL. EHS was found in slightly higher concentrations at the Atlantic Coast, but was not detected in Hong Kong and Tokyo

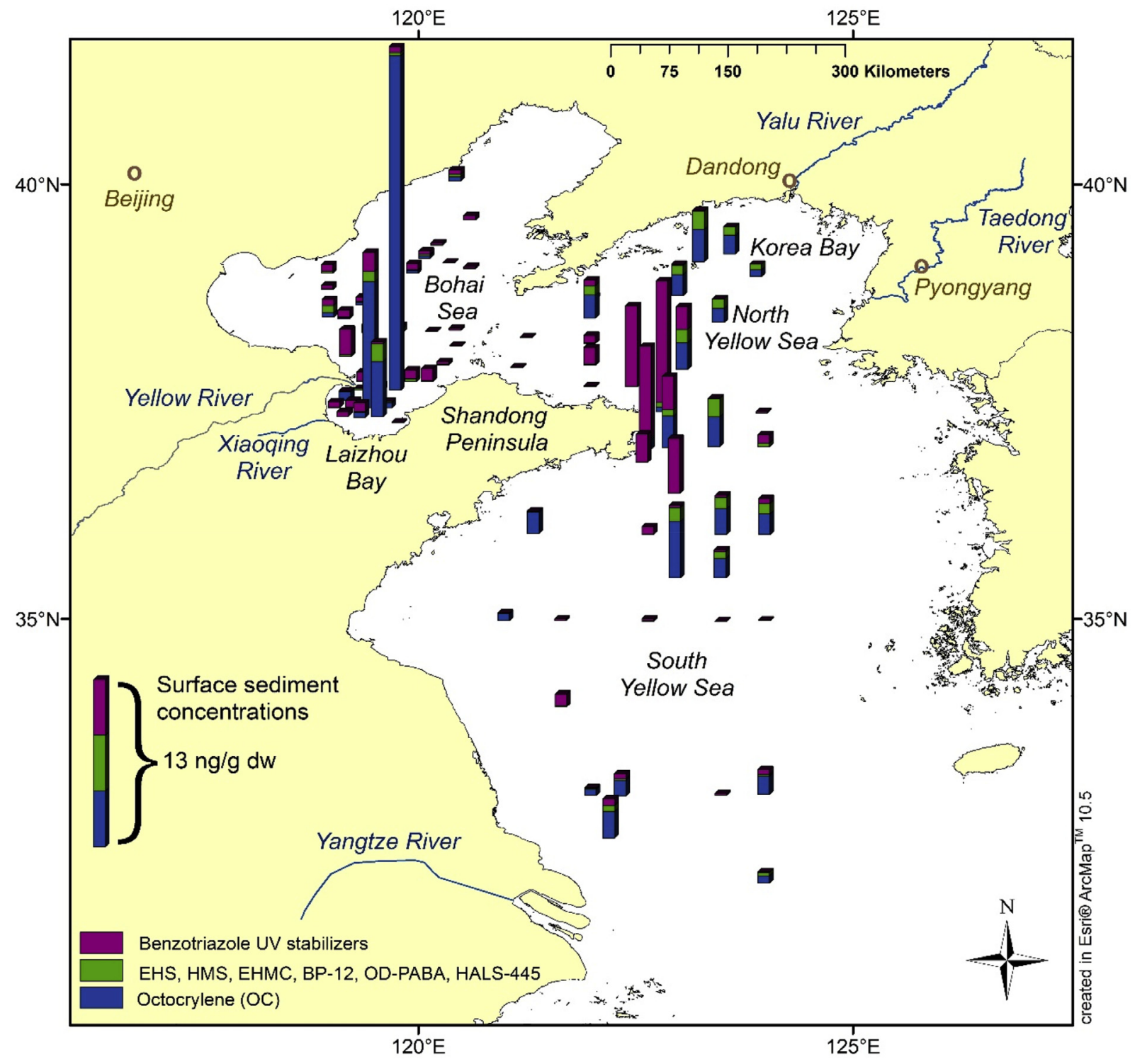

Fig. 1. UV stabilizer concentrations in surface sediments $[\mathrm{ng} / \mathrm{g} \mathrm{dw}]$ over the entire study area. 
Table 1

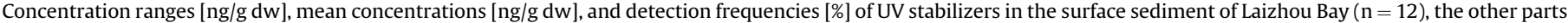
of the Bohai Sea $(n=22)$, and the Yellow Sea $(n=40)$.

\begin{tabular}{|c|c|c|c|c|c|c|c|c|c|}
\hline \multirow[t]{2}{*}{ Substance } & \multicolumn{3}{|l|}{$\begin{array}{l}\text { Laizhou Bay } \\
(\mathrm{n}=12)\end{array}$} & \multicolumn{3}{|c|}{$\begin{array}{l}\text { Bohai Sea } \\
\text { (excluding Laizhou Bay) } \\
(\mathrm{n}=22)\end{array}$} & \multicolumn{3}{|l|}{$\begin{array}{l}\text { Yellow Sea } \\
(n=40)\end{array}$} \\
\hline & $\begin{array}{l}\text { Range } \\
\text { [ng/g dw] }\end{array}$ & $\begin{array}{l}\text { Mean }^{a} \\
{[\mathrm{ng} / \mathrm{g} \mathrm{dw}]}\end{array}$ & d.f. [\%] & $\begin{array}{l}\text { Range } \\
\text { [ng/g dw] }\end{array}$ & $\begin{array}{l}\text { Mean }^{\mathrm{a}} \\
{[\mathrm{ng} / \mathrm{g} \mathrm{dw}]}\end{array}$ & d.f. [\%] & $\begin{array}{l}\text { Range } \\
\text { [ng/g dw] }\end{array}$ & $\begin{array}{l}\text { Mean }^{\mathrm{a}} \\
{[\mathrm{ng} / \mathrm{g} \mathrm{dw}]}\end{array}$ & d.f. [\%] \\
\hline UV-P & $<\mathrm{MDL}-0.02$ & $<\mathrm{MQL}$ & 50 & $<\mathrm{MDL}-0.06$ & $<\mathrm{MQL}$ & 45 & $<\mathrm{MDL}-0.06$ & 0.02 & 58 \\
\hline UV-320 & $<\mathrm{MQL}$ & $<\mathrm{MDL}$ & 8 & $<\mathrm{MDL}$ & - & 0 & $<\mathrm{MDL}-0.20$ & $<\mathrm{MQL}$ & 15 \\
\hline UV-326 & $<\mathrm{MDL}-0.75$ & 0.11 & 67 & $<\mathrm{MDL}-0.65$ & 0.12 & 82 & $<\mathrm{MDL}-1.96$ & 0.20 & 58 \\
\hline UV-327 & $<\mathrm{MDL}-0.50$ & 0.17 & 67 & $<\mathrm{MDL}-1.22$ & 0.17 & 82 & $<\mathrm{MDL}-1.23$ & 0.10 & 35 \\
\hline UV-328 & $<\mathrm{MDL}-0.16$ & 0.04 & 58 & $<\mathrm{MDL}-0.12$ & 0.04 & 91 & $<\mathrm{MDL}-0.41$ & 0.06 & 50 \\
\hline UV-329 & $<\mathrm{MDL}-0.04$ & $<\mathrm{MQL}$ & 50 & $<\mathrm{MDL}-0.09$ & $<\mathrm{MQL}$ & 73 & $<\mathrm{MDL}-6.09$ & 0.53 & 65 \\
\hline UV-234 & $<\mathrm{MDL}-0.05$ & 0.02 & 67 & $<\mathrm{MDL}-0.25$ & 0.03 & 86 & $<\mathrm{MDL}-0.39$ & 0.07 & 60 \\
\hline EHMC & $<\mathrm{MDL}-0.22$ & $<\mathrm{MQL}$ & 33 & $<\mathrm{MDL}-0.24$ & $<\mathrm{MQL}$ & 27 & $<\mathrm{MDL}-0.08$ & $<\mathrm{MDL}$ & 15 \\
\hline EHS & $<\mathrm{MDL}-1.28$ & 0.16 & 33 & $<\mathrm{MQL}$ & $<\mathrm{MDL}$ & 18 & $<\mathrm{MDL}-1.35$ & 0.26 & 63 \\
\hline HMS & $<\mathrm{MQL}$ & $<\mathrm{MDL}$ & 8 & $<\mathrm{MDL}-0.06$ & $<\mathrm{MQL}$ & 59 & $<\mathrm{MDL}-0.94$ & 0.03 & 25 \\
\hline $\mathrm{OC}$ & $<\mathrm{MDL}-25$ & 3.34 & 50 & $<\mathrm{MDL}-0.36$ & $<\mathrm{MDL}$ & 27 & $<\mathrm{MDL}-4.25$ & 0.83 & 55 \\
\hline OD-PABA & $<\mathrm{MDL}$ & - & 0 & $<\mathrm{MDL}$ & - & 0 & $<\mathrm{MDL}-0.004$ & $<\mathrm{MDL}$ & 8 \\
\hline $\mathrm{BP}-12^{\mathrm{b}}$ & $<\mathrm{MQL}$ & $<\mathrm{MQL}$ & 60 & $<\mathrm{MDL}-0.25$ & $<\mathrm{MQL}$ & 57 & $<\mathrm{MDL}-0.16$ & $<\mathrm{MQL}$ & 36 \\
\hline HALS-445 & $<\mathrm{MQL}$ & $<\mathrm{MQL}$ & 58 & $<\mathrm{MDL}-0.21$ & 0.022 & 86 & $<\mathrm{MDL}-0.18$ & 0.010 & 50 \\
\hline
\end{tabular}

a The mean value was calculated as following: The sum of concentrations in all samples was divided by the total number of samples (including samples $<$ MDL). For calculation, concentration values $<$ MDL were treated as zero and for concentration values $<$ MQL, the calculated concentration value was used.

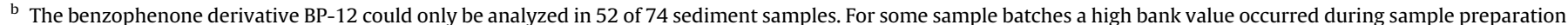
whereby an investigation of BP-12 for these samples was not possible.

Table 2

Overview of selected studies reporting UV stabilizer concentrations in coastal and marine sediments. All data are in ng/g dw.

\begin{tabular}{|c|c|c|c|c|c|c|c|c|c|}
\hline \multirow[t]{2}{*}{ UV stabilizer } & \multirow{2}{*}{$\frac{\text { This study }}{\text { Bohai and Yellow Seas, China }}$} & \multicolumn{3}{|c|}{ Tsui et al. (2015) } & \multirow{2}{*}{$\frac{\text { Nakata et al. (2009) }}{\text { Ariake Sea, Japan }}$} & \multirow{2}{*}{$\frac{\text { Langford et al. (2015) }}{\text { Oslofjord, Norway }}$} & \multicolumn{3}{|c|}{ Barón et al. (2013) } \\
\hline & & \multicolumn{2}{|c|}{ Hong Kong, China } & Tokyo Bay, Japan & & & \multicolumn{2}{|c|}{ West Coastal Line, Colombia } & Bays in Chile \\
\hline 4-MBC & $<\mathrm{MDL}$ & $<\mathrm{MDL}$ & & $<\mathrm{MDL}$ & $<\mathrm{MDL}$ & - & $<\mathrm{MDL}-7.90$ & & $<\mathrm{MDL}$ \\
\hline EHMC & $<\mathrm{MDL}-0.24$ & $0.6-447$ & & $0.3-54.5$ & - & $8.5-16.4$ & $<\mathrm{MDL}-17.8$ & & $<\mathrm{MDL}$ \\
\hline EHS & $<\mathrm{MDL}-1.35$ & $<\mathrm{MDL}$ & & $<\mathrm{MDL}$ & - & - & - & & - \\
\hline HMS & $<\mathrm{MDL}-0.94$ & $<\mathrm{MDL}$ & & $<\mathrm{MDL}$ & - & - & - & & - \\
\hline IAMC & $<\mathrm{MDL}$ & $<\mathrm{MDL}$ & & $<\mathrm{MDL}$ & - & - & - & & - \\
\hline BP-3 & $<\mathrm{MDL}$ & $0.05-39.8$ & & $<\mathrm{MDL}$ & - & $<\mathrm{MDL}$ & $<\mathrm{MDL}-2.52$ & & $<\mathrm{MDL}-1.42$ \\
\hline $\mathrm{OC}$ & $<\mathrm{MDL}-25$ & $0.04-15.6$ & & $<\mathrm{MDL}$ & - & $<\mathrm{MDL}-82.1$ & - & & - \\
\hline OD-PABA & $<\mathrm{MDL}-0.004$ & $1.5-150$ & & $0.8-13.9$ & - & $<\mathrm{MDL}$ & - & & - \\
\hline UV-234 & $<\mathrm{MDL}-0.39$ & - & & - & - & $<\mathrm{MDL}$ & - & & - \\
\hline UV-320 & $<\mathrm{MDL}-0.20$ & - & & - & $0.3-2.3$ & - & - & & - \\
\hline UV-326 & $<\mathrm{MDL}-1.96$ & - & & - & $1.5-12$ & - & - & & - \\
\hline UV-327 & $<\mathrm{MDL}-1.23$ & - & & - & $1.6-9.9$ & $<\mathrm{MDL}-8.1$ & - & & - \\
\hline UV-328 & $<\mathrm{MDL}-0.41$ & - & & - & $2.6-16$ & $3.2-25.1$ & - & & - \\
\hline UV-329 & $<\mathrm{MDL}-6.09$ & - & & - & - & $<\mathrm{MDL}$ & - & & - \\
\hline \multirow[t]{2}{*}{$\begin{array}{l}\text { UV } \\
\text { stabilizer }\end{array}$} & \multicolumn{5}{|l|}{ Pintado-Herrera et al. (2017a) } & $\begin{array}{l}\text { Combi et al. } \\
(2016)\end{array}$ & $\begin{array}{l}\text { Amine et al. } \\
(2012)\end{array}$ & \multicolumn{2}{|c|}{$\begin{array}{l}\text { Sanchez-Brunete et al. } \\
(2011)\end{array}$} \\
\hline & \multicolumn{2}{|c|}{$\begin{array}{l}\text { Cadiz Bay, Atlantic coast of Andalusia (SW } \\
\text { Spain) } \\
\text { (mean concentrations) }\end{array}$} & \multicolumn{3}{|c|}{$\begin{array}{l}\text { Huelva Estuary, Atlantic coast of Andalusia (SW } \\
\text { Spain) } \\
\text { (mean concentrations) }\end{array}$} & W Adriatic Sea & Lebanon & \multicolumn{2}{|c|}{$\begin{array}{l}\text { Spain } \\
\text { (one sediment) }\end{array}$} \\
\hline 4-MBC & \multicolumn{2}{|l|}{1.7} & \multicolumn{3}{|l|}{$<\mathrm{MDL}$} & - & - & \multicolumn{2}{|l|}{-} \\
\hline EHMC & \multicolumn{2}{|l|}{7.3} & \multicolumn{3}{|l|}{8.0} & $0.9-10.4$ & up to 9 & \multicolumn{2}{|l|}{-} \\
\hline EHS & \multicolumn{2}{|l|}{3.3} & \multicolumn{3}{|l|}{5.2} & - & - & \multicolumn{2}{|l|}{13.3} \\
\hline HMS & \multicolumn{2}{|l|}{4} & \multicolumn{3}{|l|}{1.2} & - & - & \multicolumn{2}{|l|}{$<\mathrm{MDL}$} \\
\hline IAMC & - & & - & & & - & - & - & \\
\hline BP-3 & 0.7 & & 0.9 & & & $<\mathrm{MDL}-0.23$ & - & $<\mathrm{MDL}$ & \\
\hline $\mathrm{OC}$ & 20.8 & & 15.1 & & & $0.8-40.7$ & up to 79 & - & \\
\hline OD-PABA & - & & - & & & - & up to 9 & - & \\
\hline UV-234 & - & & - & & & - & - & - & \\
\hline UV-320 & - & & - & & & - & - & - & \\
\hline UV-326 & - & & - & & & - & - & - & \\
\hline UV-327 & - & & - & & & - & - & - & \\
\hline UV-328 & - & & - & & & - & - & - & \\
\hline UV-329 & - & & - & & & - & - & - & \\
\hline
\end{tabular}

Bay sediments (Table 2). In Korea, EHS (in addition to EHMC and BP3) was a main contaminant in different environmental matrices (Ekpeghere et al., 2016; Kim et al., 2017). In the South Yellow Sea, OC and EHS were found in highest concentrations of $4.25 \mathrm{ng} / \mathrm{g} \mathrm{dw}$, and $0.95 \mathrm{ng} / \mathrm{g} \mathrm{dw}$, respectively.

Around the Shandong Peninsula, benzotriazole UV stabilizers were the most prominent substance group. The highest benzotriazole concentrations occurred at the northern tip of the 
peninsula. $\sum$ UV stabilizers was $9.82 \mathrm{ng} / \mathrm{g}$ dw with UV-329 (6.09 ng/g dw) and UV-326 (1.96 ng/g dw) as the main contributors. These concentrations were slightly lower than in sediments of the Ariake Sea and the Oslofjord, where highest concentrations of $16 \mathrm{ng} / \mathrm{g} \mathrm{dw}$ and $25 \mathrm{ng} / \mathrm{g} \mathrm{dw}$, respectively were observed for UV-328 (Table 2). In the Pearl River Estuary, UV-326 was the dominating benzotriazole UV stabilizer, followed by UV-328, UV-234, UV-P, UV329, and UV-327 (Peng et al., 2017). In German river sediments, the dominating substances were UV-360 (bisoctrizole, not analyzed in this study) and UV-326, while UV-329 was found in a median concentration of $2.2 \mathrm{ng} / \mathrm{dw}$ (Wick et al., 2016). In contrast to these reports, UV-329 was the dominating substance attributing to $42 \%$ of benzotriazole UV stabilizer contamination in this study, followed by UV-326 (23\%) and UV-327 (19\%). It can be concluded that, while benzotriazole UV stabilizers are applied worldwide, the main compounds seem to be region specific.

In recent studies, EHMC was often one of the dominant UV stabilizers in sediments, reaching concentrations of several hundred ng/g dw (Table 2). Interestingly, the concentrations found in this study are much lower even though EHMC is used in $>95 \%$ of cosmetics and sunscreens currently marketed in China (Peng et al., 2017).

While 4-MBC was one dominant contaminant in Switzerland (Balmer et al., 2005; Poiger et al., 2004), it was not detected in Japan (Table 2), where the use of 4-MBC as sunscreen ingredients is not allowed (Kameda et al., 2011). Its non-detection in this study could also be ascribed to the infrequent use of 4-MBC in currently marketed PCPs in China (Peng et al., 2017). A similar observation was made for OD-PABA. While OD-PABA was identified as one of the predominant compounds in Hong Kong and Tokyo Bay sediments (Table 2), it was only a minor contaminant in the Korean environment (Ekpeghere et al., 2016; Kim et al., 2017), where OD-PABA is not permitted in personal care products (Ekpeghere et al., 2016). In Hong Kong, Tsui et al. (2014) connected the presence of 4-MBC, IAMC and OD-PABA with recreational activities. Consequently, their absence or infrequent detection in this study indicates other sources of UV stabilizers into the Bohai and Yellow Seas.

The infrequent detection of UV-P and the non-detection of BP-3 could possibly be explained by their relatively higher water solubility (logK $\mathrm{K}_{\mathrm{W}}$-values are 3.00 and 3.52, respectively) compared to the other UV stabilizers analyzed in this study $\left(4<\log \mathrm{K}_{\mathrm{OW}} \leq 17\right.$, Table S1 of the Supplementary Material). Furthermore, BP-3 is not a major UV stabilizer in sunscreens in China (Liao and Kannan, 2014).

\subsection{Distribution pattern of UV stabilizers}

While most UV stabilizers are distributed quite homogeneously over the Bohai Sea sampling area, there is an entry of OC into Laizhou Bay. OC has wide dispersive uses in PCPs and other industrial products (ECHA, 2017b). While recreational activities such as swimming (Poiger et al., 2004; Sanchez Rodriguez et al., 2015) are the major input pathway of $\mathrm{OC}$ into the environment in other regions, Laizhou Bay is strongly affected by land-based pollutants imported from rivers. Among the rivers leading into the Laizhou Bay, both the Yellow River and the Xiaoqing River are the most important regarding contamination discharges (Heydebreck et al., 2015; Yu et al., 2017). The OC distribution with elevated levels in the Laizhou Bay could possibly be explained by riverine inputs followed by a deposition in the central and outer Laizhou Bay. This agrees with the flow-current patterns (Qiao et al., 2010) in this area.

In the North Yellow Sea, the distribution of UV stabilizers is very interesting. In Korea Bay, OC and EHS are the dominant substances. In contrast to this, benzotriazole UV stabilizers are the most prominent substance group around the Shandong Peninsula. This change in regional contamination composition is graphically shown in Fig. 2. The different composition profiles of UV stabilizers in Korea Bay and around the Shandong Peninsula are mixing together in the central North Yellow Sea. This distribution pattern indicates different sources of UV stabilizers deposited into the North Yellow Sea.

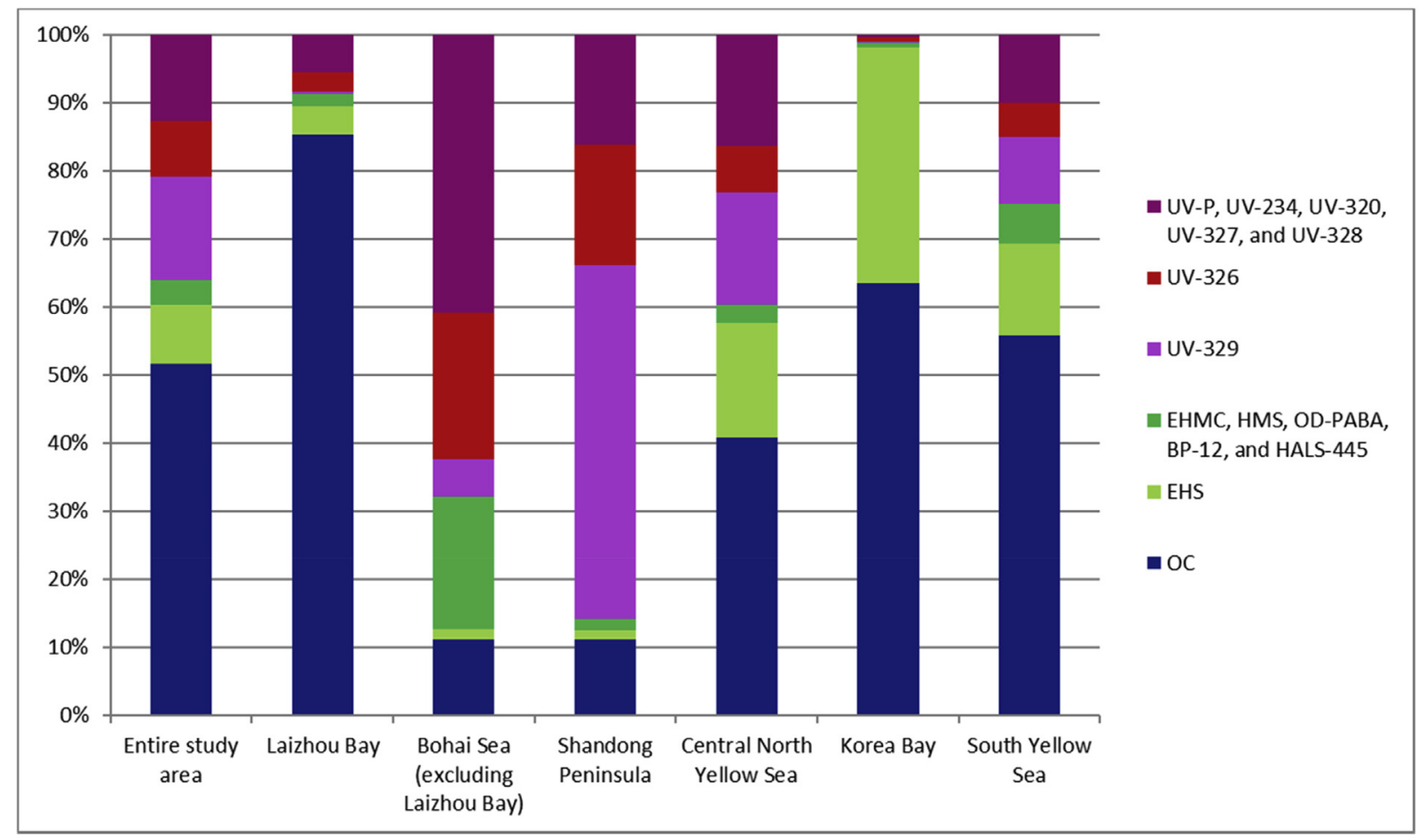

Fig. 2. Composition profiles of UV stabilizers in different regions of the Bohai and Yellow Seas. 
Like OC, EHS is used in sunscreens worldwide and environmental contaminations are therefore often connected to recreational activities (Sankoda et al., 2015; Tashiro and Kameda, 2013). In Korea Bay however, a direct input through recreational activities seems unlikely, especially as all other compounds approved in sunscreens were $<$ MQL. A moderate correlation of OC and EHS in North Yellow Sea sediments $(r=0.83, p<.01)$ indicates identical sources for both compounds in this region. Apart from recreational activities, the incomplete removal of UV stabilizers in wastewater and sewage treatment plants is a major contributor to their occurrence in the environment (Ekpeghere et al., 2016; Tsui et al., 2014). In South Korea, EHS (in addition to EHMC) was the most dominant contaminant in rivers receiving sewage treatment plant discharges, mainly from domestic origins (Ekpeghere et al., 2016; Kim et al., 2017). Riverine inputs (e.g., the Yalu River forming the border between China and North Korea or the North Korean Taedong River, Fig. 1) derived from domestic or industrial discharges might also be the most likely contamination source in Korea Bay.

Around the Shandong Peninsula the concentrations of the benzotriazole derivatives UV-326 and UV-329 showed a strong correlation $(\mathrm{r}>0.98, \mathrm{p}$ « 0.01$)$. In addition, a moderate correlation could be observed between UV-234 and UV-327 ( $\mathrm{r}>0.82, \mathrm{p}=.01$ ). The correlation between the other benzotriazole derivatives UV326, UV-327, UV-328, UV-329, and UV-234 was poor $(\mathrm{r}<0.7$; $\mathrm{p}>$ .02 ). In conclusion, these substances, especially UV-326 and UV329 , seemed to derive from the same sources and to behave similarly in the environment. A correlation between concentrations of benzotriazole UV stabilizers was also reported by Wick et al. (2016) in German river sediments and Nakata et al. (2009) in sediments of the Japanese Ariake Sea even though other substances correlated most. Kameda et al. (2011) investigated the occurrence of UV stabilizers in rivers in Japan and noticed that benzotriazole UV stabilizers accumulated particularly in sediment receiving chemical plant effluent, residential wastewaters, sewage treatment plant effluent, and surface runoff. Similar sources seem likely to be responsible for the detected benzotriazole contamination at the Shandong Peninsula. In China, benzotriazole UV stabilizers are present in sewage sludge collected from wastewater treatment plants, with UV-234, UV-326, UV-329, and UV-328 being the dominant compounds (Ruan et al., 2012; Song et al., 2014). Since most benzotriazole UV stabilizers (except UV-P) are almost completely removed from the final effluent (Liu et al., 2012; Song et al., 2014), the direct effluent discharge of wastewater treatment plants only seems to be of minor importance as a contamination source in this case. In sewage sludge however, benzotriazole UV stabilizers are present in the final stage (Liu et al., 2012) and could reach the environment due to biosolid applications in agriculture. This was demonstrated by Lai et al. (2014) who investigated the occurrence of benzotriazole UV stabilizers in biosolid-amended soils. They positively detected several compounds in soils, with UV329 being the dominant substance and with the highest concentrations in Shandong (up to $33.3 \pm 7.3 \mathrm{ng} / \mathrm{g}$ ). The results by Lai et al. (2014) underline the importance of UV-329 as a characteristic contaminant in this region and also indicate surface runoff as an important contamination source of UV stabilizers introduced into the environment. Benzotriazole UV stabilizers could then be transported into the Yellow Sea via rivers.

Going south from Korea Bay into the South Yellow Sea, the pollution characteristics of Shandong Peninsula and Korea Bay are mixing together as they do in the central North Yellow Sea (Fig. 2). The highest UV stabilizer concentrations were found in the northern central part of the South Yellow Sea, where a mud area is located (Yang et al., 2003). Going further to the south or to coastal regions (with the exception of the Shandong Peninsula), UV stabilizer concentrations decrease. Two possible sources of South
Yellow Sea contaminations are the Yangtze and Yellow Rivers (Fig. 1). Lan et al. (2007) recognized Yangtze River-specific sediment compositions in South Yellow Sea sediments. Yang and Liu (2007) showed that Yellow River-derived sediment is transported from the Bohai Sea along the Shandong Peninsula coast into the South Yellow Sea. The contaminations found in this study are more likely to originate from the Yangtze River and to be transported by ocean currents (Zhong et al., 2018) into the South Yellow Sea. Yellow River-derived contamination seems unlikely, as the contamination pattern changes drastically over the described sediment transportation pathway.

\subsection{Correlation with TOC}

The TOC content in the analyzed sediment samples ranged from 0.03 to $0.87 \%$ (Table S7, Supplementary Material). In Fig. S3 of the Supplementary Material, UV stabilizer concentrations are plotted against the TOC content of each sample. No correlation could be observed $(\mathrm{r}=0.09, \mathrm{p}=.44)$. This is consistent with recent studies (Gago-Ferrero et al., 2011; Huang et al., 2016; Tsui et al., 2015). So far, only Nakata et al. (2009) revealed a positive correlation between benzotriazole UV stabilizer concentrations and the TOC content in samples from the Ariake Sea, Japan. The TOC content in the Ariake Sea samples ranged from 2 to $15 \%$, which are much higher values compared to those in this study. The lacking correlation in this study could be due to several reasons, such as an inhomogeneous distribution over the sampling area or the ability of UV stabilizers to partition to other phases in dynamic aquatic environments (Tsui et al., 2015). Too low UV stabilizer concentrations (in most samples) or a too narrow TOC range could also result in an indiscernible correlation.

\subsection{Qualitative information on DBT and EHT in marine sediments}

In addition to the findings presented in Fig. 1 and Table 1, the UV stabilizers DBT and EHT could be identified in several samples of the Bohai Sea and the Yellow Sea. Because of low recoveries, low reproducibility, and lack of appropriate mass-labeled standards, the applied method is not suitable for quantifying these compounds. Estimated concentrations of the triazine derivatives DBT and EHT in some samples are in the high ng/g dw range. As an example, disregarding possible matrix effects and assuming a theoretical recovery rate of $5 \%$, the concentrations are $750 \mathrm{ng} / \mathrm{g} \mathrm{dw}$ for DBT and $150 \mathrm{ng} / \mathrm{g} \mathrm{dw}$ for EHT at the tip of the Shandong Peninsula. Even assuming a recovery rate of $100 \%$, the concentrations are $40 \mathrm{ng} / \mathrm{g}$ $\mathrm{dw}$ and $8 \mathrm{ng} / \mathrm{g} \mathrm{dw}$, respectively, and are therefore comparable to or even higher than those of other UV stabilizers in this study. In addition to their use in industrials materials, these substances are approved as ingredients in sunscreen products in Europe (European Commission, 2017), China (following the European Cosmetic Directive), and Australia (only EHT) (Australian Government, 2017). DBT and EHT are highly hydrophobic compounds with calculated $\log \mathrm{K}_{\mathrm{ow}}$ values $>14$ (Table S1, Supplementary Material), resulting in a high accumulation potential in sediment. So far, environmental data on these compounds are sparse. They have been measured in sewage sludge at concentration levels of several hundred $\mathrm{ng} / \mathrm{g} \mathrm{dw}$ (Kupper et al., 2006; Plagellat et al., 2006; Rodil et al., 2009) and in wastewater (Kupper et al., 2006). To the best of the authors' knowledge, this is the first time these substances have been found in marine sediments. Further investigations of environmental levels and behavior should be conducted.

\subsection{Potential environmental risk}

While it has been demonstrated that UV stabilizers pose a risk to 
aquatic organisms (Sanchez Rodriguez et al., 2015; Tsui et al., 2014), only few studies reported sediment toxicity data and investigated the ecotoxicological impact on benthic organisms, which are especially affected by hydrophobic substances.

In vivo toxicity values are available only for EHMC and 4-MBC (Kaiser et al., 2012; Schmitt et al., 2008) for invertebrates. Using these data, Tsui et al. (2015) evaluated the probabilistic risk of sediment associated with EHMC (up to $447 \mathrm{ng} / \mathrm{g} \mathrm{dw}$, Table 2). They found it to be $>30 \%$ and $>80 \%$ in both Hong Kong and Tokyo Bay for the different species. The calculated risk to fish was lower than $20 \%$, but due to their high lipophilicity, UV stabilizers may still pose a threat to aquatic organisms at higher trophic levels by entering the food chain. Using both in vivo and predicted toxicity data, preliminary risk assessments were carried out for six UV stabilizers (OC, EHS, HMS, BP-3, 4-MBC, and EHMC) that were present in the sediment from the Atlantic Coast (Pintado-Herrera et al., 2017a) and of the Pearl River Estuary (Pintado-Herrera et al., 2017b). At both sites, the HQs for two substances (EHMC and 4-MBC) were $>1$ and therefore pose a risk to benthic species.

In the present study, the environmental concentrations were lower than in the regions described above. As 4-MBC and BP-3 levels were $<\mathrm{MDL}$ in all samples, a potential risk evaluation was only carried out for OC, EHMC, EHS, and HMS. The PNEC values used for calculation are listed in Table S8 (Supplementary Material). The HQ values were $<1$ for all substances in all samples, which means that according to present knowledge, no adverse effects of UV stabilizers for benthic species are expected in the Bohai and Yellow Seas.

\section{Conclusions}

This study provides environmental levels of UV stabilizers in the Chinese Bohai and Yellow Seas for the first time. 16 out of 21 analyzed UV stabilizers have been identified in marine sediments pointing out the presence of UV stabilizer not only in limnic, riverine, estuarine, and coastal systems but also in the marine environment. They occur ubiquitously over the entire sampling area, underlying the importance for further investigations on their occurrence and impact on these ecosystems. Characteristic pollution profiles and distribution pattern have been identified, which indicate different sources of UV stabilizers introduced into the study area. The results suggest that the Chinese Bohai and Yellow Seas are contaminated mainly by indirect sources via riverine input. More focus should be given to highly hydrophobic UV stabilizers such as triazine derivatives, which could be an important but so far overlooked group of emerging contaminants. Because of limited information available, an environmental risk assessment of UV stabilizers in the investigated area is not yet possible even though a preliminary risk evaluation does not indicate any risk for sedimentassociated organisms in the Bohai and Yellow Seas. More sediment toxicity data for benthic organisms are urgently needed to fill this gap in knowledge.

\section{Acknowledgements}

This study was supported by the Chinese Academy of Sciences (XDA11020401, KZZD-EW-14, 2013T2Z0032, and 13337KYSB20130013). We gratefully thank the crews of the research vessels Dongfanghong 2 and Chuangxin 1 for their assistance.

\section{Appendix A. Supplementary data}

Supplementary data related to this article can be found at https://doi.org/10.1016/j.envpol.2017.12.051.

\section{References}

Amine, H., Gomez, E., Halwani, J., Casellas, C., Fenet, H., 2012. UV filters, ethylhexyl methoxycinnamate, octocrylene and ethylhexyl dimethyl PABA from untreated wastewater in sediment from eastern Mediterranean river transition and coastal zones. Mar. Pollut. Bull. 64, 2435-2442. https://doi.org/10.1016 j.marpolbul.2012.07.051.

Australian Government, 2017. Australian Regulatory Guidelines for Sunscreens (ARGS). https://www.tga.gov.au/book/9-permitted-ingredients\#s91. Accessed 05/2017.

Avagyan, R., Luongo, G., Thorsen, G., Ostman, C., 2015. Benzothiazole, benzotriazole, and their derivates in clothing textiles-a potential source of environmental pollutants and human exposure. Environ Sci Pollut Res Int 22, 5842-5849. https://doi.org/10.1007/s11356-014-3691-0.

Balazs, A., Krifaton, C., Orosz, I., Szoboszlay, S., Kovacs, R., Csenki, Z., Urbanyi, B. Kriszt, B., 2016. Hormonal activity, cytotoxicity and developmental toxicity of UV filters. Ecotoxicol. Environ. Saf. 131, 45-53. https://doi.org/10.1016/ j.ecoenv.2016.04.037.

Balmer, M.E., Buser, H.R., Müller, M.D., Poiger, T., 2005. Occurrence of some organic UV filters in wastewater, in surface waters, and in fish from Swiss lakes. Environ. Sci. Technol. 39, 953-962.

Barón, E., Gago-Ferrero, P., Gorga, M., Rudolph, I., Mendoza, G., Zapata, A.M., DiazCruz, S., Barra, R., Ocampo-Duque, W., Paez, M., Darbra, R.M., Eljarrat, E., Barcelo, D., 2013. Occurrence of hydrophobic organic pollutants (BFRs and UVfilters) in sediments from South America. Chemosphere 92, 309-316. https:// doi.org/10.1016/j.chemosphere.2013.03.032.

Cole, M., Lindeque, P., Halsband, C., Galloway, T.S., 2011. Microplastics as contaminants in the marine environment: a review. Mar. Pollut. Bull. 62, 2588-2597. https://doi.org/10.1016/j.marpolbul.2011.09.025.

Combi, T., Pintado-Herrera, M.G., Lara-Martin, P.A., Miserocchi, S., Langone, L., Guerra, R., 2016. Distribution and fate of legacy and emerging contaminants along the Adriatic Sea: a comparative study. Environ. Pollut. 218, 1055-1064. https://doi.org/10.1016/j.envpol.2016.08.057.

Cunha, S.C., Fernandes, J.O., Vallecillos, L., Cano-Sancho, G., Domingo, J.L., Pocurull, E., Borrull, F., Maulvault, A.L., Ferrari, F., Fernandez-Tejedor, M., Van den Heuvel, F., Kotterman, M., 2015a. Co-occurrence of musk fragrances and UV-filters in seafood and macroalgae collected in European hotspots. Environ. Res. 143, 65-71. https://doi.org/10.1016/j.envres.2015.05.003.

Cunha, S.C., Pena, A., Fernandes, J.O., 2015b. Dispersive liquid-liquid microextraction followed by microwave-assisted silylation and gas chromatography-mass spectrometry analysis for simultaneous trace quantification of bisphenol $\mathrm{A}$ and 13 ultraviolet filters in wastewaters. J. Chromatogr. A 1414, 10-21. https:// doi.org/10.1016/j.chroma.2015.07.099.

Danovaro, R., Bongiorni, L., Corinaldesi, C., Giovannelli, D., Damiani, E., Astolfi, P., Greci, L., Pusceddu, A., 2008. Sunscreens cause coral bleaching by promoting viral infections. Environ. Health Perspect. 116, 441-447. https://doi.org/10.1289/ ehp.10966.

ECHA, 2017a. Candidate List of Substances of Very High Concern for Authorisation. https://echa.europa.eu/web/guest/candidate-list-table. Accessed 09/2017.

ECHA, 2017b. Substance Information on Octocrilene. https://echa.europa.eu/de/ substance-information/-/substanceinfo/100.025.683. Accessed 11/2017.

Ekpeghere, K.I., Kim, U.J., O, S.H., Kim, H.Y., Oh, J.E., 2016. Distribution and seasonal occurrence of UV filters in rivers and wastewater treatment plants in Korea. Sci. Total Environ. 542, 121-128. https://doi.org/10.1016/j.scitotenv.2015.10.033.

European Commission, 2015. COMMISSION IMPLEMENTING DECISION (EU) 2015 495 of 20 March 2015 establishing a watch list of substances for Union-wide monitoring in the field of water policy pursuant to Directive 2008/105/EC of the European Parliament and of the Council. Official J. Eur. Union. L 78/40 - L $78 / 42$.

European Commission, 2017. Cosmetic Ingredient Database. https://ec.europa.eu/ growth/sectors/cosmetics/cosing_de. Accessed 05/2017.

Fent, K., Chew, G., Li, J., Gomez, E., 2014. Benzotriazole UV-stabilizers and benzotriazole: antiandrogenic activity in vitro and activation of aryl hydrocarbon receptor pathway in zebrafish eleuthero-embryos. Sci. Total Environ. 482-483, 125-136. https://doi.org/10.1016/j.scitotenv.2014.02.109.

Gago-Ferrero, P., Diaz-Cruz, M.S., Barcelo, D., 2012. An overview of UV-absorbing compounds (organic UV filters) in aquatic biota. Anal. Bioanal. Chem. 404, 2597-2610. https://doi.org/10.1007/s00216-012-6067-7.

Gago-Ferrero, P., Díaz-Cruz, M.S., Barceló, D., 2011. Fast pressurized liquid extraction with in-cell purification and analysis by liquid chromatography tandem mass spectrometry for the determination of UV filters and their degradation products in sediments. Anal. Bioanal. Chem. 400, 2195-2204. https://doi.org/10.1007/ s00216-011-4951-1.

Heydebreck, F., Tang, J., Xie, Z., Ebinghaus, R., 2015. Alternative and legacy perfluoroalkyl substances: differences between European and Chinese river/estuary systems. Environ. Sci. Technol. https://doi.org/10.1021/acs.est.5b01648.

Huang, W., Xie, Z., Yan, W., Mi, W., Xu, W., 2016. Occurrence and distribution of synthetic musks and organic UV filters from riverine and coastal sediments in the Pearl River estuary of China. Mar. Pollut. Bull. https://doi.org/10.1016/ j.marpolbul.2016.07.018.

Kaiser, D., Sieratowicz, A., Zielke, H., Oetken, M., Hollert, H., Oehlmann, J., 2012 Ecotoxicological effect characterisation of widely used organic UV filters. Environ. Pollut. 163, 84-90. https://doi.org/10.1016/j.envpol.2011.12.014.

Kameda, Y., Kimura, K., Miyazaki, M., 2011. Occurrence and profiles of organic sun- 
blocking agents in surface waters and sediments in Japanese rivers and lakes. Environ. Pollut. 159, 1570-1576. https://doi.org/10.1016/j.envpol.2011.02.055.

Kim, J.W., Chang, K.H., Isobe, T., Tanabe, S., 2011a. Acute toxicity of benzotriazole ultraviolet stabilizers on freshwater crustacean (Daphnia pulex). J. Toxicol. Sci. 36, 247-251.

Kim, J.W., Isobe, T., Malarvannan, G., Sudaryanto, A., Chang, K.H., Prudente, M. Tanabe, S., 2012. Contamination of benzotriazole ultraviolet stabilizers in house dust from the Philippines: implications on human exposure. Sci. Total Environ. 424, 174-181. https://doi.org/10.1016/j.scitotenv.2012.02.040.

Kim, J.W., Isobe, T., Ramaswamy, B.R., Chang, K.H., Amano, A., Miller, T.M. Siringan, F.P., Tanabe, S., 2011b. Contamination and bioaccumulation of benzotriazole ultraviolet stabilizers in fish from Manila Bay, the Philippines using n ultra-fast liquid chromatography-tandem mass spectrometry. Chemosphere 85, 751-758. https://doi.org/10.1016/j.chemosphere.2011.06.054.

Kim, K.Y., Ekpeghere, K.I., Jeong, H.J., Oh, J.E., 2017. Effects of the summer holiday season on UV filter and illicit drug concentrations in the Korean wastewater system and aquatic environment. Environ. Pollut. 227, 587-595. https:/ doi.org/10.1016/j.envpol.2017.04.055.

Kupper, T., Plagellat, C., Brandli, R.C., de Alencastro, L.F., Grandjean, D., Tarradellas, J. 2006. Fate and removal of polycyclic musks, UV filters and biocides during wastewater treatment. Water Res. 40, 2603-2612. https://doi.org/10.1016/ j.watres.2006.04.012.

Lai, H.J., Ying, G.G., Ma, Y.B., Chen, Z.F., Chen, F., Liu, Y.S., 2014. Occurrence and dissipation of benzotriazoles and benzotriazole ultraviolet stabilizers in biosolid-amended soils. Environ. Toxicol. Chem. 33, 761-767. https://doi.org/ $10.1002 /$ etc. 2498

Lan, X., Wang, H., Li, R., Lin, Z., Zhang, Z., 2007. Major elements composition and provenance analysis in the sediments of the south Yellow sea. Earth Sci. Front. 14, 197-203. https://doi.org/10.1016/s1872-5791(07)60033-5.

Langford, K.H., Reid, M.J., Fjeld, E., Oxnevad, S., Thomas, K.V., 2015. Environmenta occurrence and risk of organic UV filters and stabilizers in multiple matrices in Norway. Environ. Int. 80,1-7. https://doi.org/10.1016/j.envint.2015.03.012.

Liao, C., Kannan, K., 2014. Widespread occurrence of benzophenone-type UV light filters in personal care products from China and the United States: an assessment of human exposure. Environ. Sci. Technol. 48, 4103-4109. https://doi.org/ $10.1021 /$ es405450n.

Liu, R., Ruan, T., Wang, T., Song, S., Guo, F., Jiang, G., 2014. Determination of nine benzotriazole UV stabilizers in environmental water samples by automated online solid phase extraction coupled with high-performance liquid chromatography-tandem mass spectrometry. Talanta 120, 158-166. https:/ doi.org/10.1016/j.talanta.2013.10.041.

Liu, Y.S., Ying, G.G., Shareef, A., Kookana, R.S., 2012. Occurrence and removal of benzotriazoles and ultraviolet filters in a municipal wastewater treatment plant. Environ. Pollut. 165, 225-232. https://doi.org/10.1016/ j.envpol.2011.10.009.

Nagayoshi, H., Kakimoto, K., Takagi, S., Konishi, Y., Kajimura, K., Matsuda, T., 2015 Benzotriazole ultraviolet stabilizers show potent activities as human aryl hydrocarbon receptor ligands. Environ. Sci. Technol. 49, 578-587. https://doi.org 10.1021/es503926w.

Nakata, H., Murata, S., Filatreau, J., 2009. Occurrence and concentrations of benzotriazole UV stabilizers in marine organisms and sediments from the Ariake sea. Japan. Environ. Sci. Technol 43, 6920-6926.

Nakata, H., Shinohara, R., Nakazawa, Y., Isobe, T., Sudaryanto, A., Subramanian, A. Tanabe, S., Zakaria, M.P., Zheng, G.J., Lam, P.K., Kim, E.Y., Min, B.Y., We, S.U. Viet, P.H., Tana, T.S., Prudente, M., Frank, D., Lauenstein, G., Kannan, K., 2012. Asia-Pacific mussel watch for emerging pollutants: distribution of synthetic musks and benzotriazole UV stabilizers in Asian and US coastal waters. Ma Pollut. Bull. 64, 2211-2218. https://doi.org/10.1016/j.marpolbul.2012.07.049.

OECD, 2017. HPV Database. http://webnet.oecd.org/HPV/UI/Search.aspx. Accessed $05 / 2017$.

Peng, X., Jin, J., Wang, C., Ou, W., Tang, C., 2015. Multi-target determination of organic ultraviolet absorbents in organism tissues by ultrasonic assisted extraction and ultra-high performance liquid chromatography-tandem mass spectrometry. J. Chromatogr. A 1384, 97-106. https://doi.org/10.1016 j.chroma.2015.01.051.

Peng, X., Xiong, S., Ou, W., Wang, Z., Tan, J., Jin, J., Tang, C., Liu, J., Fan, Y., 2017 Persistence, temporal and spatial profiles of ultraviolet absorbents and phenolic personal care products in riverine and estuarine sediment of the Pearl River catchment, China. J. Hazard Mater. 323, 139-146. https://doi.org/10.1016 j.jhazmat.2016.05.020.

Pintado-Herrera, M.G., Combi, T., Corada-Fernandez, C., Gonzalez-Mazo, E., LaraMartin, P.A., 2017a. Occurrence and spatial distribution of legacy and emerging organic pollutants in marine sediments from the Atlantic coast (Andalusia, SW Spain). Sci. Total Environ. 605-606, 980-994. https://doi.org/10.1016/ j.scitotenv.2017.06.055

Pintado-Herrera, M.G., Wang, C., Lu, J., Chang, Y.P., Chen, W., Li, X., Lara-Martin, P.A., 2017b. Distribution, mass inventories, and ecological risk assessment of legacy and emerging contaminants in sediments from the Pearl River Estuary in China. J. Hazard Mater. 323, 128-138. https://doi.org/10.1016/j.jhazmat.2016.02.046.

Plagellat, C., Kupper, T., Furrer, R., de Alencastro, L.F., Grandjean, D., Tarradellas, J., 2006. Concentrations and specific loads of UV filters in sewage sludge originating from a monitoring network in Switzerland. Chemosphere 62, 915-925. https://doi.org/10.1016/j.chemosphere.2005.05.024.

Poiger, T., Buser, H.-R., Balmer, M.E., Bergqvist, P.-A., Müller, M.D., 2004. Occurrence of UV filter compounds from sunscreens in surface waters: regional mass balance in two Swiss lakes. Chemosphere 55, 951-963. https://doi.org/10.1016/ j.chemosphere.2004.01.012.

Qiao, S.Q., Shi, X.F., Zhu, A.M., Liu, Y.G., Bi, N.S., Fang, X.S., Yang, G., 2010. Distribution and transport of suspended sediments off the Yellow River (Huanghe) mouth and the nearby Bohai sea. Estuar. Coast Shelf Sci. 86, 337-344. https://doi.org/ 10.1016/j.ecss.2009.07.019.

Rainieri, S., Barranco, A., Primec, M., Langerholc, T., 2017. Occurence and toxicity of musks and UV filters in the marine environment. Food Chem. Toxicol. 104, 57-68.

Ramos, S., Homem, V., Alves, A., Santos, L., 2015. Advances in analytical methods and occurrence of organic UV-filters in the environment - a review. Sci. Total Environ. 526, 278-311. https://doi.org/10.1016/j.scitotenv.2015.04.055.

Ramos, S., Homem, V., Alves, A., Santos, L., 2016. A review of organic UV-filters in wastewater treatment plants. Environ. Int. 86, 24-44. https://doi.org/10.1016/ j.envint.2015.10.004

Rani, M., Shim, W.J., Han, G.M., Jang, M., Al-Odaini, N.A., Song, Y.K., Hong, S.H., 2015 Qualitative analysis of additives in plastic marine debris and its new products. Arch. Environ. Contam. Toxicol. 69, 352-366. https://doi.org/10.1007/s00244015-0224-X.

Rani, M., Shim, W.J., Han, G.M., Jang, M., Song, Y.K., Hong, S.H., 2017. Benzotriazoletype ultraviolet stabilizers and antioxidants in plastic marine debris and their new products. Sci. Total Environ. 579, 745-754. https://doi.org/10.1016/ j.scitotenv.2016.11.033.

Rodil, R., Schrader, S., Moeder, M., 2009. Pressurised membrane-assisted liquid extraction of UV filters from sludge. J. Chromatogr. A 1216, 8851-8858. https:// doi.org/10.1016/j.chroma.2009.10.058.

Ruan, T., Liu, R., Fu, Q., Wang, T., Wang, Y., Song, S., Wang, P., Teng, M., Jiang, G., 2012. Concentrations and composition profiles of benzotriazole UV stabilizers in municipal sewage sludge in China. Environ. Sci. Technol. 46, 2071-2079. https://doi.org/10.1021/es203376x.

Sanchez-Brunete, C., Miguel, E., Albero, B., Tadeo, J.L., 2011. Analysis of salicylate and benzophenone-type UV filters in soils and sediments by simultaneous extraction cleanup and gas chromatography-mass spectrometry. J. Chromatogr. A 1218, 4291-4298. https://doi.org/10.1016/j.chroma.2011.05.030.

Sanchez Rodriguez, A., Rodrigo Sanz, M., Betancort Rodriguez, J.R., 2015. Occurrence of eight UV filters in beaches of Gran Canaria (Canary Islands). An approach to environmental risk assessment. Chemosphere 131, 85-90. https://doi.org/ 10.1016/j.chemosphere.2015.02.054.

Sang, Z., Leung, K.S., 2016. Environmental occurrence and ecological risk assessment of organic UV filters in marine organisms from Hong Kong coastal waters. Sci. Total Environ. 566-567, 489-498. https://doi.org/10.1016/ j.scitotenv.2016.05.120

Sankoda, K., Murata, K., Tanihata, M., Suzuki, K., Nomiyama, K., Shinohara, R., 2015. Seasonal and diurnal variation of organic ultraviolet filters from personal care products used along the Japanese coast. Arch. Environ. Contam. Toxicol. 68, 217-224. https://doi.org/10.1007/s00244-014-0106-7.

Schmitt, C., Oetken, M., Dittberner, O., Wagner, M., Oehlmann, J., 2008. Endocrine modulation and toxic effects of two commonly used UV screens on the aquatic invertebrates Potamopyrgus antipodarum and Lumbriculus variegatus. Environ. Pollut. 152, 322-329. https://doi.org/10.1016/j.envpol.2007.06.031.

Song, J., 2010. Biogeochemical Processes of Biogenic Elements in China Marginal Seas. Springer-Verlag Berlin Heidelberg.

Song, S., Ruan, T., Wang, T., Liu, R., Jiang, G., 2014. Occurrence and removal of benzotriazole ultraviolet stabilizers in a wastewater treatment plant in China. Environ Sci Process Impacts 16, 1076-1082. https://doi.org/10.1039/ c3em00483j.

Tashiro, Y., Kameda, Y., 2013. Concentration of organic sun-blocking agents in seawater of beaches and coral reefs of Okinawa Island, Japan. Mar. Pollut. Bull. 77, 333-340. https://doi.org/10.1016/j.marpolbul.2013.09.013.

Tsui, M.M., Leung, H.W., Kwan, B.K., Ng, K.Y., Yamashita, N., Taniyasu, S., Lam, P.K., Murphy, M.B., 2015. Occurrence, distribution and ecological risk assessment of multiple classes of UV filters in marine sediments in Hong Kong and Japan. J. Hazard Mater. 292, 180-187. https://doi.org/10.1016/j.jhazmat.2015.03.025.

Tsui, M.M., Leung, H.W., Wai, T.C., Yamashita, N., Taniyasu, S., Liu, W., Lam, P.K., Murphy, M.B., 2014. Occurrence, distribution and ecological risk assessment of multiple classes of UV filters in surface waters from different countries. Water Res. 67, 55-65. https://doi.org/10.1016/j.watres.2014.09.013.

Wang, J., Pan, L., Wu, S., Lu, L., Xu, Y., Zhu, Y., Guo, M., Zhuang, S., 2016. Recent advances on endocrine disrupting effects of UV filters. Int. J. Environ. Res. Publ. Health 13. https://doi.org/10.3390/ijerph13080782.

Wang, P., Lu, Y., Wang, T., Fu, Y., Zhu, Z., Liu, S., Xie, S., Xiao, Y., Giesy, J.P., 2014. Occurrence and transport of 17 perfluoroalkyl acids in 12 coastal rivers in south Bohai coastal region of China with concentrated fluoropolymer facilities. Environ. Pollut. 190, 115-122. https://doi.org/10.1016/j.envpol.2014.03.030.

Wang, R., Tang, J., Xie, Z., Mi, W., Chen, Y., Wolschke, H., Tian, C., Pan, X., Luo, Y., Ebinghaus, R., 2015. Occurrence and spatial distribution of organophosphate ester flame retardants and plasticizers in 40 rivers draining into the Bohai Sea, north China. Environ. Pollut. 198, 172-178. https://doi.org/10.1016/ j.envpol.2014.12.037.

Wick, A., Jacobs, B., Kunkel, U., Heininger, P., Ternes, T.A., 2016. Benzotriazole UV stabilizers in sediments, suspended particulate matter and fish of German rivers: new insights into occurrence, time trends and persistency. Environ. Pollut. 212, 401-412. https://doi.org/10.1016/j.envpol.2016.01.024.

Yamano, T., Shimizu, M., Noda, T., 2001. Relative elicitation potencies of seven chemical allergens in the Guinea pig maximization test. J. Health Sci. 47, 
$123-128$.

Yang, S.Y., Jung, H.S., Lim, D.I., Li, C.X., 2003. A review on the provenance discrimination of sediments in the Yellow Sea. Earth Sci. Rev. 63, 93-120. https:// doi.org/10.1016/S0012-8252(03)00033-3.

Yang, Z.S., Liu, J.P., 2007. A unique Yellow River-derived distal subaqueous delta in the Yellow Sea. Mar. Geol. 240, 169-176. https://doi.org/10.1016/ j.margeo.2007.02.008

Yu, S.X., Pang, Y.L., Wang, Y.C., Li, J.L., Qin, S., 2017. Spatial variation of microbial communities in sediments along the environmental gradients from Xiaoqing River to Laizhou Bay. Mar. Pollut. Bull. 120, 90-98. https://doi.org/10.1016/ j.marpolbul.2017.04.059.

Zhang, Y., Johnson, A.C., Su, C., Zhang, M., Jurgens, M.D., Shi, Y., Lu, Y., 2017. Which persistent organic pollutants in the rivers of the Bohai Region of China represent the greatest risk to the local ecosystem? Chemosphere 178, 11-18 https://doi.org/10.1016/j.chemosphere.2017.02.137.

Zhong, M., Wu, H., Mi, W., Li, F., Ji, C., Ebinghaus, R., Tang, J., Xie, Z., 2018. Occurrences and distribution characteristics of organophosphate ester flame retardants and plasticizers in the sediments of the Bohai and Yellow Seas, China. Sci. Total Environ. 615, 1305-1311. https://doi.org/10.1016 j.scitotenv.2017.09.272.

Zhuang, S., Wang, H., Ding, K., Wang, J., Pan, L., Lu, Y., Liu, Q., Zhang, C., 2016. Interactions of benzotriazole UV stabilizers with human serum albumin: atomic insights revealed by biosensors, spectroscopies and molecular dynamics simulations. Chemosphere 144, 1050-1059. https://doi.org/10.1016 j.chemosphere.2015.09.085. 